\title{
Financial Performance and Economic Growth of Government in the Province of Papua in the Pandemic
}

\author{
Wa Ariadi ${ }^{1},{ }^{*}$ M. Anas ${ }^{2}$, Muhammad Yasser Fedayyen ${ }^{3}$, Tiolina Evi ${ }^{4}, \mathrm{Irma}^{5}$, \\ Heny Sidanti ${ }^{6}$
}

\author{
${ }^{1}$ Dept. Masters Management of Sekolah Tinggi Ilmu Ekonomi Port Numbay, Jayapura Papua, Indonesia \\ ${ }^{2}$ Dept. Masters in Economic Education of Nusantara PGRI University, Kediri, Indonesia \\ ${ }^{3}$ Dept. Public Administration, University of Sintuwu Moroso Poso, Central Sulawesi, Indonesia \\ ${ }^{4}$ Accounting Department Perbanas Institute, Jakarta, Indonesia \\ ${ }^{5}$ Dept. Accounting Department STIE Panca Bhakti Palu, Indonesia \\ ${ }^{6}$ Dept. Management, of PGRI University, Madiun, Indonesia \\ *Corresponding author.Email: waariadi@gmail.com
}

\begin{abstract}
The study on the analysis of the Papua Provincial Government's financial performance during the pandemic aims to determine the development of Regional Original Revenue and direct expenditure budgets, and the effect of Regional Original Revenue (PAD) and direct expenditure on economic growth. This research was a descriptive quantitative study using time series data from 2016-2020 which data source was secondary data from the Papua Provincial Government budget realization report. Papua Provincial Government in 2020 experienced a decline of $22.76 \%$. This decline was of course due to the COVID-19 pandemic which resulted in the implementation of a restriction or lockdown policy to limit the movement of people in an effort to suppress the spread of the virus. While the results of the analysis of the effect of local revenue and capital expenditure on economic growth indicate that local revenue has a negative and insignificant effect, while capital expenditure has a positive but not significant effect.
\end{abstract}

Keywords: Local Revenue, Capital Expenditure and Economic Growth.

\section{INTRODUCTION}

Regional autonomy is an effort to accelerate national development evenly, from cities to remote areas so that all people in the region can enjoy development and have a better life. The basis of the implementation of autonomy is to provide flexibility, be valid and responsible so that it is expected to notice the aspects of democracy, participation, fairness and equity while still taking into account the potential and diversity of the region. With this foundation, regional autonomy is expected to be a means of accelerating the creation of community welfare in the regions [12]. The welfare of the community is the main target of the implementation of autonomy and national development as predetermined when the reform was applied. This goal can only become reality by prioritizing services that are oriented to the interests of the people to reach remote areas both in quality and quantity.

According [6],[2] the objectives of regional autonomy are basically directed at accelerating equitable distribution of development and its results, improving people's welfare, activating community dynamics, increasing the utilization of regional capabilities clearly, optimal, integrated, dynamic, and consistent manner so as to strengthen national unity and integrity. Reduce the load on the central government and interference with the regions and provide opportunities for synchronization at the local or regional level. [8] conveys the things that cause the failure of local governments to realize autonomy as the followings: the amount of transfers and the center of governance, the regional companies are not yet optimal in increasing local own-source revenue (PAD), the high degree of centralization in the taxation sector, [4] The source of local tax revenue is quite large but the revenue is very small. Weaknesses in the delivery of grant from the central government to local governments.

Since the implementation of special autonomy, Papua Province has developed rapidly in various fields, including regional expansion, infrastructure development, economic development and political development [16]. This shows that the granting of authority to the provincial government is not only financial but also the central government's trust in local governments to manage resources in improving development and the economy of the community to remote areas has been conducted with the hope that the 
implementation of expansion is expected to be one of the a development mobility to remote areas and can improve people's welfare.

Papua Province with an area of $312,224.37 \mathrm{~km}^{2}$ with a total of 28 regencies and 1 city is the largest and widest province with access to reach between regencies is still very limited, so that the distribution of development is still not evenly distributed in all fields. With the number of priority programs, it certainly requires a large budget. The priorities for the 2019-2023 medium-term Papua regional development program as have been prepared according to strategic objectives, affairs, authorities, spending policies (direct spending/indirect spending), as well as the main ones in each customary area [7].

The amount of the regional budget is certainly expected to be used in such a way for public service providers in realizing development from upstream to downstream in order to improve the welfare of the community which can be measured through the Human Development Index. It is a combination of outcome performance indicators from several provincial and district/city work units that can be used. The welfare level itself indicated by economic performance, level of education and health [3].

\section{LITERATURE REVIEW}

According to [1] budget is an instrument that is used as a guide in creating productivity progress, development, economic development and increasing production capacity and per capita income in an effort to realize success in the welfare of society. The budget can also be used as a tool for future expenditure authority, a coordinating tool for all activities in various work units and a standard measure for performance evaluation [9]. According to [10], performance is the level of achievement of the implementation of a policy in order to realize the goals, vision and mission of the organization contained in the strategic planning of an organization.

Optimizing regional financial management must pay attention to two aspects such as aspects of income and expenditure; however, regional expenditure management must receive more dominant attention than revenue management, because spending money is much easier than getting money [11],[17]. This is often faced with certain conditions where saving the budget is more difficult than pursuing revenue targets. In carrying out more accurate, efficient and effective regional financial management, local governments need to implement the principles of accurate, permanent and sustainable regional expenditure management [19]. Regional taxes are mandatory donations to regions that are imposed by individuals or entities in accordance with the rules and legislation without receiving direct compensation and used for regional purposes for the welfare of the people.

According to [5],[13] direct expenditure is divided into five groups likes land capital budget, equipment, capital budget, office or building capital expenditure, road capital expenditure, bridges, and other material capital budgets. The financing budget for capital also has two forms, public expenditure for investment programs and personnel expenditure which is a budget for public services.

\section{RESEARCH METHODS}

This research was a type of descriptive associative research, a research that had a direction to understand the cause and effect of two or more variables used to describe, predict and observe a phenomenon [15] The object of this research was the financial performance of the Papua Provincial Government. The type of research data was secondary data in the form of Budget Realization Reports (LRA) and economic growth.

\section{RESULTS AND DISCUSSION}

The analysis of the Papua Province government's financial performance through the growth ratio for local Own-Source Revenue and Capital Expenditures during 2016-2020 shows as the following figure (1)

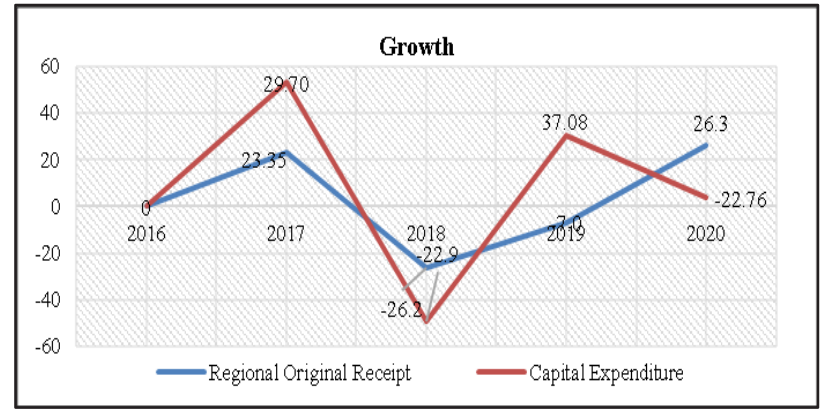

Source: Budget Realization Reports (processed), 2021

Figure 1. Development of Direct Expenditure

The development of the Local own-source revenue (PAD) of the Papua Province for the last five years has shown an unstable development, but in 2020 the PAD actually increased to $26.3 \%$, although in 2018 and 2019 there was a decline. The growth of the direct expenditure budget or known as capital expenditure also experienced unstable growth although in 2019 there was an increase of $37.08 \%$ but in 2020 there was a decrease in the budget for capital expenditure reaching $22.76 \%$. This decline is of course due to the COVID-19 pandemic which resulted in the implementation of a restriction or lockdown policy to limit the movement of people in an effort to suppress the spread of the virus.

The results of the analysis of the impact of local revenue and direct expenditure on economic growth as the results of the analysis with secondary data sources from the Papua Provincial Government Budget Realization Report is shown as in table 1 below:

Table 1. Results of Moderated Regression Analysis

\begin{tabular}{|c|c|c|c|c|c|}
\hline \multirow[b]{2}{*}{ Model } & \multicolumn{2}{|c|}{ Unstandardized Coefficients } & $\begin{array}{c}\text { Standardi } \\
\text { zed } \\
\text { Coefficie } \\
\text { nts }\end{array}$ & & \\
\hline & B & Std. Error & Beta & $\mathrm{t}$ & Sig. \\
\hline
\end{tabular}




\begin{tabular}{|l|r|r|r|r|r|}
\hline $1 \quad$ (Constant) & 604,669 & 1393,695 & &, 434 &, 707 \\
\cline { 2 - 6 } $\begin{array}{l}\text { Local own- } \\
\text { source revenue } \\
\text { capital expenditure }\end{array}$ & $-7,278 \mathrm{E}-10$ &, 000 &,- 439 &,- 714 &, 550 \\
\cline { 2 - 6 } & $1,023 \mathrm{E}-10$ &, 000 &, 364 &, 591 &, 614 \\
\hline R & $: 0,517$ & & & \\
Adj. R Square (R2) & $: 0,465$ & $: 0,701$ &
\end{tabular}

Data Source: Processed, 2021

The results of the analysis of the correlation between PAD and capital expenditure on economic growth shown that the value of $\mathrm{R}=0.517$, while the value of the coefficient of determination was $=0.465$. These results shows that the correlation between the independent variable and the dependent variable could be stated having a strong correlation, while the influence of the two variables of Regional Original Income and direct expenditure on economic growth had an insignificant impact where the effect only reached $46.5 \%$ which mean that the increase in revenue from Regional Original Revenue and capital expenditure is influenced by indicators and other variables outside the regression model by $53.5 \%$.

The results of the analysis are confirmed by the regression equation as follows $\mathrm{Y}=604.669-7,278 \mathrm{X} 1+$ $1.023 \mathrm{X} 2$. From this equation, it can be explained that

if Local own-source revenue (PAD) spending and capital expenditures are eliminated by the government, economic growth will remain at 604.669. The magnitude of the X1 coefficient of -7.278 indicates that if Local own-source revenue revenue decreases, it will cause a decrease in economic growth by $7.28 \%$, and if there is an increase in the capital expenditure budget by $1 \%$, it will increase economic growth by $1.023 \%$. The significant level for Local own-source revenue is -.714 with a significance level of 0.550 , so it is concluded that Local own-source revenue (PAD) has a negative and insignificant effect on economic growth.

The significant test value of the Capital Expenditure variable is 0.591 with a significant level of 0.614 , which means that direct spending has a positive but not significant effect on economic growth.

\section{CONCLUSION}

The results of this analysis shows that local revenue shows that revenue is still not stable even though in 2020 there was an increase, and the Papua Province government's capital expenditure budget in 2020 has decreased to $22.76 \%$. While the results of the analysis of the influence of PAD and capital expenditure on economic growth show that local revenue has a negative and insignificant effect, while capital expenditure has a positive but not significant effect.

\section{AUTHORS' CONTRIBUTIONS}

All authors fully contribute starting from the preparation of topics, research data, and review of research results.

\section{ACKNOWLEDGMENT}

The author teams are grateful to CEL KODELN, ICESEBE Comitee and Makasar State University (UNM).

\section{REFERENCES}

[1] Agus Samekto (2011) The Impact of Budget Decentralization on Local Government Performance (Study on District/City in Jawa Timur).

[2] Adi, Priyo Hari. (2006) The Relationship Between Regional Economic Growth, Development Expenditures and Regional Original Income (Studies on Regencies and Cities throughout JavaBali)". National Accounting Symposium in Padang Sumatera.

[3] Anasmen. (2009) Effect of Government Capital Expenditure on Economic Growth in West Sumatra Province: 2000-2006. Thesis. Depok: Masters Program in Planning and Public Policy, University of Indonesia.

[4] Ashaton, A. H. (1995). Experience and error Frequency Knowlegde as Potencial Determinants of Audit Expertise, The Accuating Review,66

[5] Anggiat Situngkir (2009) Economic Growth, Regional Original Income, General Allocation Funds and Special Allocation Funds affect Capital Expenditures at the Pemko/Regency of North Sumatra

[6] Bastian, Indra, (2001), Public Sector Accounting in Indonesia. First Edition. Yogyakarta: BPFE, UGM.

[7] Bappeda Papua 2019-2023 Papua Province Medium Term Development Plan 2019-2023

[8] Darwanto, Yulia Yustikasari, (2007) Influence of Economic Growth of Regional Original Income and General Allocation Funds on Capital Expenditure Budget Allocation, National Accounting Symposium X. Makassar.

[9] Dobell Piter dan Ulrich Martin, (2002).Parliaments performance in the budget proses: A case study Policy Matters; 3(2) http//www.irpp.org.

[10] Kuncoro Mudrajat (2004) Regional Autonomy and Regional Development: Reform, Planning, Strategy and Opportunity. Jakarta: Erlangga.

[11] Mahsun (2006), Public Sector Performance Measurement, Yogyakarta,BPEF

[12] Mardiasmo (2002), Regional Autonomy as an Effort to Strengthen the Regional Economic Base. Journal of People's Economy, Article Th. I No. 4 June 2002. Jakartaa. 
[13] Nugroho, Fajar. 2012. Effect of Capital Expenditure on Regional Financial Performance With Local Revenue As an Intervening Variable (Case Study in Central Java Province). Diponegoro University.

[14] Sasana, Hadi. (2015). Impact of Fiscal Decentralization Implementation on Economic Growth and Price Stability in Provinces in Indonesia. Media Economics And Management, Vol. 30, No. 1.

[15] Sugiyono. (2016). Metode Penelitian Kuantitatif, Kualitatif dan R\&D. Bandung: PT Alfabet.

16] Robbins, Stephen P (1993) "Managing Organizational Conflict”, A.Non-Traditional Approach Upper Saddle River,N.J.Prentl,Hall

[17] Olatunji, O.C., O. Asaolu Taiwo and J.O. Adewoye. 2009. A Review of Revenue Generation in Nigeria Local Government: A Case Study of Ekiti State. Journal of International Business Management, Vol.3, Issue 3, pp: 54-60

[18] Wong John D. (2004).The Fiscal Impact of Economi Grouwth and Developmen on Local Goverment Capacity, Journal Of Public Budgeting, Accouting and Financial management,p.413-423 